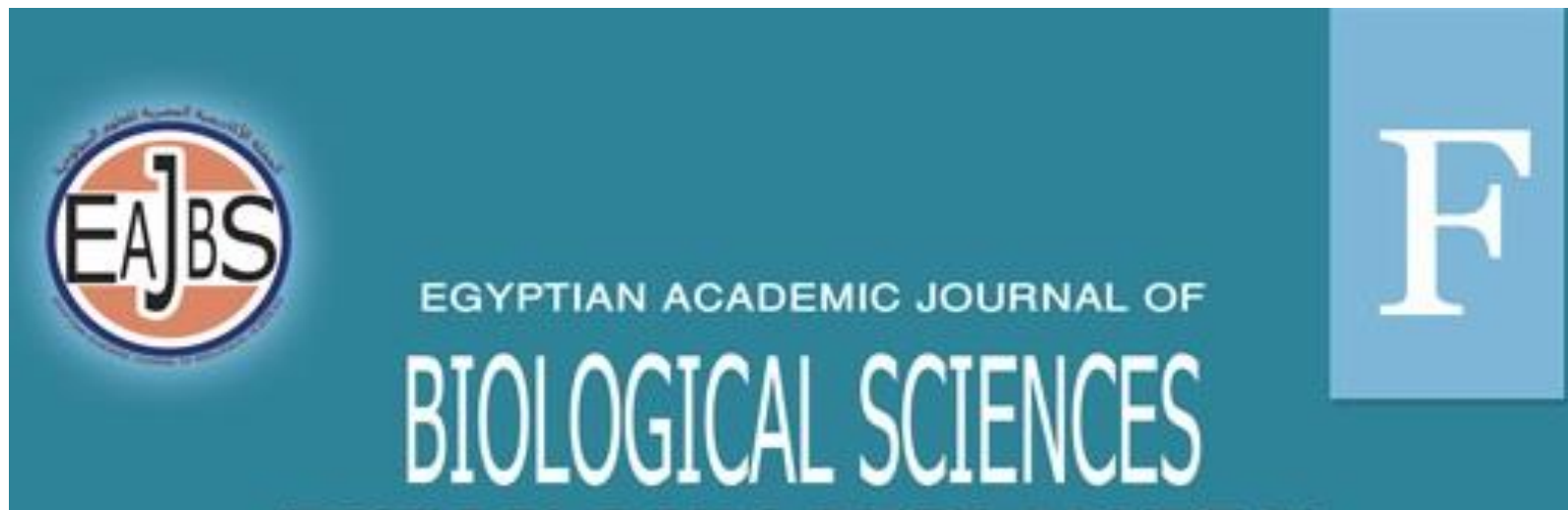

TOXICOLOGY \& PEST CONTROL

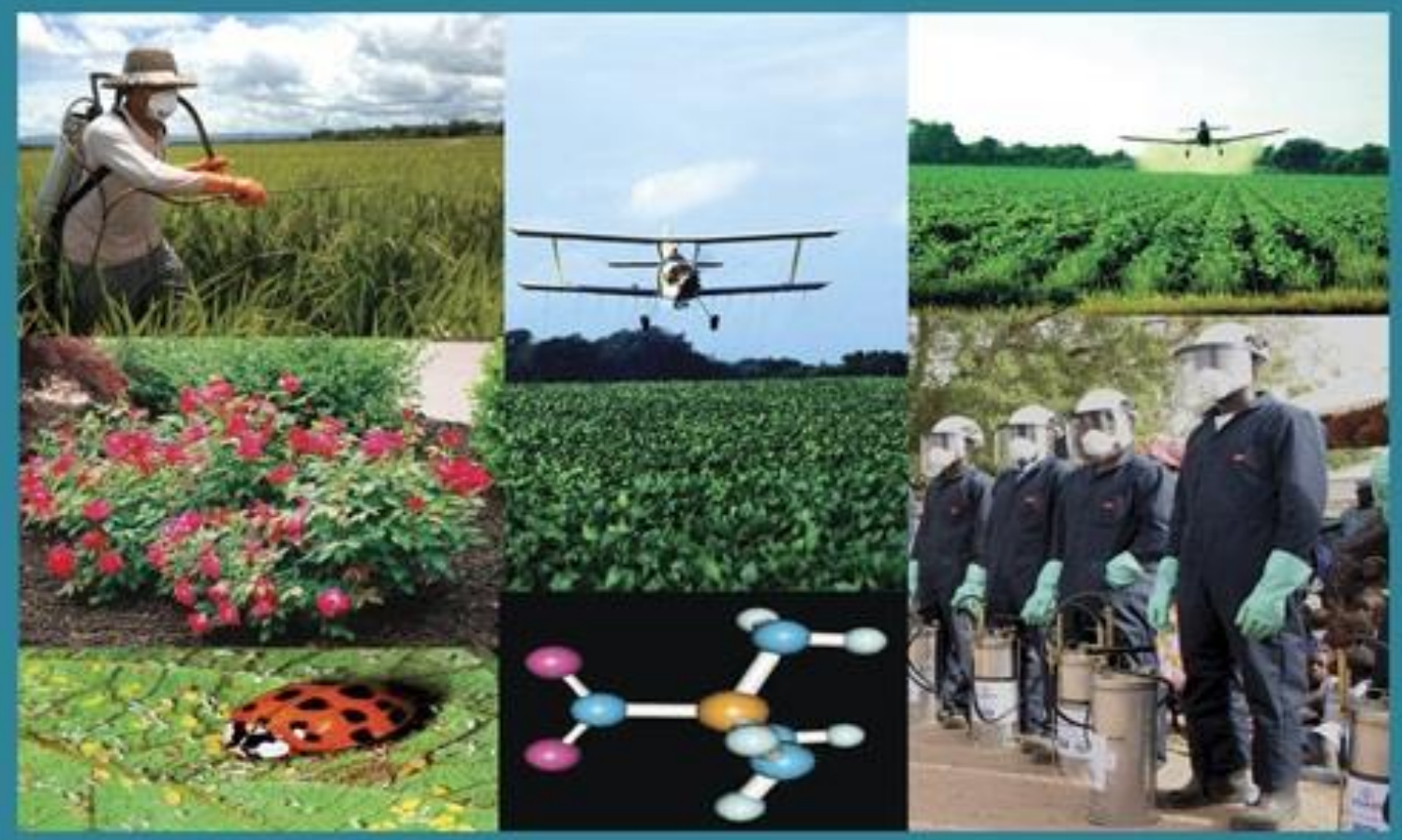

ISSN

2090-0791

WWW.EAJBS.EG.NET

Vol. 13 No. 2 (2021)

Citation: Egypt. Acad. J. Biolog. Sci. (F.Toxicology\& Pest control) Vol.13(2)pp71-81(2021) DOI: $10.21608 /$ EAJBSF.2021.187542 
Egypt. Acad. J. Biolog. Sci., 13(2):71-81(2021)

\begin{tabular}{c}
$\begin{array}{c}\text { Egyptian Academic Journal of Biological Sciences } \\
\text { F. Toxicology \& Pest Control } \\
\text { ISSN: 2090 - 0791 } \\
\text { http://eajbsf.journals.ekb.eg/ }\end{array}$ \\
\hline
\end{tabular}

\title{
Effect of Biological Insecticide, Chemical Insecticide and Phosphate Fertilizer on Callosobruchus maculatus (F) (Coleoptera: Chrysomelidae) and Rhyzopertha dominica (F.) (Coleoptera: Bostrychidae)
}

\author{
Rasha Essameldin Saber ${ }^{1}$; Mawaheb Mahmoud Zewar ${ }^{1}$ and Mohamed Abdelsattar ${ }^{2}$ \\ 1-Plant Protection Research Institute, Stored Products Department, Agriculture Research \\ Center. \\ 2-Agricultural Engineering Research Institute, Department of Plant Molecular Biology \\ Agriculture Research Center. \\ E-mai1*rashaessam35@gmail.com
}

ARTICLEINFO

Article History

Received: 28/5/2021

Accepted: 25/7/2021

\section{Keywords:}

Vicia faba., Triticum

durum.,Callosobruchus

maculatus.,

Rhyzopertha

dominica., chemical

insecticide., biological

insecticide and

phosphate fertilizer

\section{ABSTRACT}

This study was carried out to evaluate toxicity and residual effect of chemical insecticide deltamethrin, biological insecticide Beauveria bassianaa and phosphate fertilizer. This Evaluation was conducted against Callosobruchus maculatus (F.) adults and Rhyzopertha dominica (F.). Results indicated that biological insecticide was the most effective material that still kills adults of $C$. maculatus and $R$. dominica till the end of the storage period (3months). The chemical insecticide caused a complete death for $C$. maculatus adults till the end of the storage period while it decreased with time for adults of $R$. dominica. All treatments did not affect seed germination and water absorption.

\section{INTRODUCTION}

According to the United Nations Food and Agriculture Organization (FAO), agricultural production must increase by $50 \%$ by 2050 to meet global food demand. (Barian L. Beres et al., 2020). The quality of the seeds sown is critical to the successful production of any crop (Rasha et al., 2017). Storage pest has become an increasing threat to food safety; losses over 30\% or more have been recorded in Africa (Lale \& Ofuya, 2001).

Faba bean (Vicia faba L.) and Durum wheat (Triticum durum Desf.) are the most important food crops in the world. Faba beans have high protein contents they are a good source of minerals, vitamins, and numerous bioactive compounds. They have an important role in maintaining the sustainability of the agricultural system, as it is a very efficient crop in the symbiotic fixation of atmospheric nitrogen (Anestis et al., 2018).

Durum wheat is no longer just a staple crop for food security but it has become a major cash crop. The industry of pasta and couscous currently purchase durum grain at prices 10 to $20 \%$ higher than bread wheat (Sall A.T. et al., 2019).

Callosobruchus maculatus (Bean beetle) is one of the most important and devastating pests belonging to order Coleoptera and family Chrysomelidae. It is a major pest of economically 
important leguminous seeds. This weevil is reported to cause up to $100 \%$ loss of stored cowpeas, causing severe qualitative and quantitative losses (Lale 1991).

Lesser grain borer Rhyzopertha dominica (F.) (Coleoptera: Bostrychidae) is a destructive pest of stored grain, (Potter, 1935; Edde, 2012). $R$. dominica generally infests stored wheat during the summer. They bore irregularly shaped holes and the larvae may develop inside the grain (Potter 1935). Larva and adults feeding in and on grain kernels may leave only dust and thin brown shells (A. S. A. Saad et al., 2018).

To avoid the disadvantages of chemical protectants, the use of natural products and some living organisms has been confirmed.Deltamethrin is a member of the chemical class of pyrethroids which are synthetic chemicals modeled after the pyrethrin components of pyrethrum and is one of the highly applicable insecticides (Marijana Pražić Golić et al., 2018). Beauveria bassiana is an entomo-pathogenic fungi which evaluated as good alternatives to chemical insecticides (Muhammad Akmal et al., 2017). Fertilizers improve crop yield also influence crop suitability for insect development (Van Emden, 1966; Wooldbridge and Harrison, 1968; Kogan, 1994, Asiwe, J. A. N et al., 2009)

\section{MATERIALS AND METHODS}

\section{Plant Materials:}

Seeds of Vicia faba cultivar Noubaria 1 and grains Triticum durum of (BaniSweif 5) were used as tested plants.

\section{Tested Insect:}

A laboratory colony of Callosobrucus maculatus and Rhizopertha dominica were kept under laboratory conditions of $28 \pm 1^{\circ} \mathrm{C}$ and $65 \pm 5 \% \mathrm{RH}$ in Stored Grains Pest Research Department, Plant Protection Research Institute, Agriculture Research Center, Dokki, Giza, Egypt. Adults (1- 2 days old for C. maculatus / 1- 2 weeks old for $R$. dominica).

Chemical insecticide deltamethrin, biological insecticide beauveria bassiana and phosphate salt fertilizer (Table 1).

Table 1: Tested materials.

\begin{tabular}{|l|c|c|c|c|}
\hline No & Trade name & Company & Active ingredient & Physical properties \\
\hline $\mathbf{1}$ & $\begin{array}{c}\text { Delta- tox } \\
5 \% \text { Ec }\end{array}$ & $\begin{array}{c}\text { Arabian Chemical } \\
\text { industries (ACI) }\end{array}$ & deltamethrin 5\% & liquid \\
\hline $\mathbf{2}$ & Biosect & $\begin{array}{c}\text { Kafr El zayat pesticides } \\
\text { and chemicals co. }\end{array}$ & $\begin{array}{c}\text { beauveria bassiana } \\
32 \times 10^{12} / \mathrm{kg}\end{array}$ & powder \\
\hline $\mathbf{3}$ & Superelfalah & $\begin{array}{c}\text { Egypt for fertilizers and } \\
\text { chemicals (Afco) }\end{array}$ & $\begin{array}{c}\text { phosphate salt } \\
30 \% \mathrm{P} 2 \mathrm{O} 5\end{array}$ & granules \\
\hline
\end{tabular}

\section{Toxicological Studies:}

A sample of $10 \mathrm{~g}$ of disinfected faba bean or wheat seeds was placed in a glass tube $(3 \times 7.5 \mathrm{~cm})$ and separately mixed with each concentration of tested materials as shown in Table (2). The tubes were shaken vigorously to ensure a uniform coating of faba bean and wheat seeds with the tested materials. Three replicates for every treatment were infested by 25 adults (1- 2 days old for C. maculatus / 1- 2 weeks old for $R$. dominica) of the tested insect. The tubes were covered secured with elastic bands and kept in the incubator under constant conditions of $28 \pm 1^{\circ} \mathrm{c}$ and $65 \pm 5 \% \mathrm{RH}$. Mortality counts of $C$. maculates and Rhyzopertha dominica adults were recorded in all experimental treatments after 1 day for $\mathrm{C}$. maculates and 3 days for Rhyzopertha dominica from exposure. The percentage of mortality was taken and was calculated according to Abbott's (1925). The slope values of established lines, LC25, LC50, LC75, LC90, LC95 and LC99 were estimated after 1 day for C. maculates and 3 days from insect exposure (Bliss, 1935). 


\section{Residual Activity of the Tested Materials on $C$. maculatus and $R$. dominica at Storage Periods:}

Each tested concentration of LC95 of detamethrin, beauveria bassiana and phosphate salt fertilizer was mixed to500 gm of $V$. faba seeds/ T. durum grains separately. They were kept in a glass jar, covered tightly under laboratory conditions of $28 \pm 1^{\circ} \mathrm{C}$. Treated seeds were stored for a duration of 3 months. Mortality of C. maculatus and Rhyzopertha dominica adults were carried out every two weeks till 3 months (Finney, 1971) by adding Twenty-five adults of $C$. maculatus/ R. dominica to $10 \mathrm{gm}$ of $V$.faba seeds/ T. durum grains of each of the three replicates in the presence of untreated control. The mortality values were corrected by using Abbott's (1925) formula.

\section{Seeds/ Grains Germination:}

$100 \mathrm{~g}$ of faba bean or wheat seeds were taken and treated with LC95 of deltamethrin, beauveria bassiana and phosphate salt fertilizer. Twenty-five $V$. faba seeds/ wheat grains were placed in Petri dishes; lined with two layers of cotton and filter paper then soaked with water. Each treatment and control were replicated four times using untreated control. After three days, germinated grains were recorded (Anonymus, 1966). The percentage of germination was calculated and the percentage of reduction in germination was determined. The above steps were repeated at the end of the storage period to determine the percentage of germination.

\section{Water Absorbance:}

$V$. faba seeds/ T. durum grains (5gm) were treated with $\mathrm{LC}_{95}$ for each protectant and then placed in tubes measuring $3 \times 7.5 \mathrm{~cm}$ immersed in water with an untreated sample which was considered as a control sample. Each sample was replicated 3 times. The increase in seeds weight was recorded after different times of treatment (1, 4, and 24 hours) according to (Schoonhoven, 1978). The aforementioned steps were repeated after 90 days to estimate the percentages of water absorption after the end of the storage period.

\section{RESULTS AND DISCUSSION}

The mortality percentage of $C$. maculatus after one day of exposure to Vicia faba treated with different concentrations of deltamethrin, B. bassiana, and phosphate salt increased with increasing concentration. the highest value $85.33 \%$ observed for seeds treated with $0.05 \mathrm{ml} / \mathrm{kg}$ of deltamethrin, $85.00 \%$ after treatment with $6.4 \times 10^{10}$ cell $/ \mathrm{kg}$ of Buvaria bassiana and $84.00 \%$ with $1.8 \mathrm{gm} / \mathrm{kg}$ of phosphate salt (Table 2) and Figure(1).

Table 2: Mortality percentage of $C$. maculatus adult after treatments Vicia faba with different concentrations of deltamethrin, Buvaria basssiana and phosphate fertilizer.

\begin{tabular}{|c|c|c|}
\hline Tested materials & $\begin{array}{c}\text { Rate of } \\
\text { treatment }\end{array}$ & $\begin{array}{c}\text { Mortality \% } \\
\text { after 1 day }\end{array}$ \\
\hline & $5 \times 10^{-5}$ & 16.0052 .00 \\
1- Chemical insecticide & $5 \times 10^{-4}$ & 64.0085 .33 \\
Deltamethrin (ml/kg) & $5 \times 10^{-3}$ & \\
& 0.05 & \\
\hline & $9.6 \times 10^{9}$ & 25.3330 .67 \\
2- Bio-insecticide & $1.6 \times 10^{10}$ & 64.0085 .00 \\
Buvaria bassiana & $3.2 \times 10^{10}$ & 100.0 \\
(cell/kg) & $6.4 \times 10^{10}$ & \\
& $9.6 \times 10^{10}$ & \\
\hline & 0.15 & 33.3357 .33 \\
3- Fertilizer superelfalah & 0.6 & 78.6784 .00 \\
(Phosphate salt gm/kg) & 1.5 & \\
& 1.8 & \\
\hline
\end{tabular}



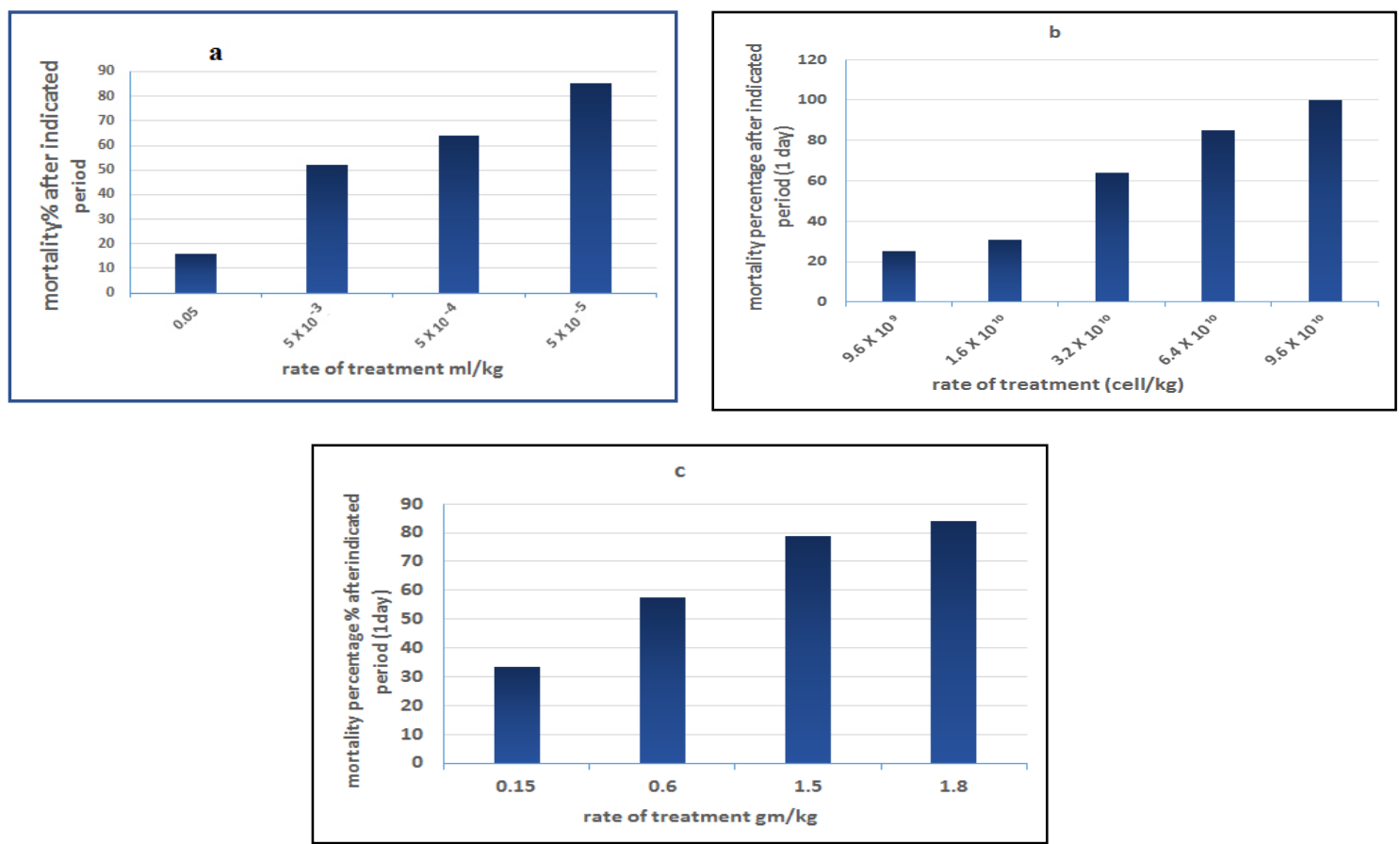

Fig.1: Mortality percentage of $C$. maculatus adult after different treatments with deltamethrin (a), Buvaria bassiana (b) and phosphate salt (C).

For $R$. dominica the mortality percentage after exposure to $T$. durum seeds treated with tested materials for 3 days increased with increasing concentration. mortality recorded $81.33 \%$ when wheat grains were treated with $5 \times 10^{-4} \mathrm{ml} / \mathrm{kg}$ of deltamethrin; $97.33 \%$ when treated with $1.28 \times 10^{10}$ cell $/ \mathrm{kg}$ of Buvaria bassiana and $84.00 \%$ when treated with $1.2 \mathrm{gm} / \mathrm{kg}$ of phosphate salt (Table 3) and Figure (2). This agrees with (Z. Mahdneshin et al., 2009, Yacoub Ahmad Batta., 2008).

Table 3: Mortality percentage of $R$. dominica adult after treatments $T$. durum with different concentrations of the deltamethrin, Buvaria basssiana and phosphate salt.

\begin{tabular}{|c|c|c|}
\hline Tested materials & $\begin{array}{c}\text { Rate of } \\
\text { treatment }\end{array}$ & $\begin{array}{c}\text { Mortality \% } \\
\text { after 3 days }\end{array}$ \\
\hline & $5 \times 10^{-7}$ & 38.00 \\
1- Chemical insecticide & $5 \times 10^{-6}$ & 68.00 \\
Deltamethrin (ml/kg) & $5 \times 10^{-5}$ & 74.67 \\
& $5 \times 10^{-4}$ & 81.33 \\
\hline & $1.6 \times 10^{10}$ & 36.00 \\
2- Bio-insecticide Buvaria & $3.2 \times 10^{10}$ & 57.33 \\
bassiana (cell/kg) & $6.4 \times 10^{10}$ & 76.00 \\
& $9.6 \times 10^{10}$ & 86.67 \\
& $1.28 \times 10^{10}$ & 97.33 \\
\hline & 0.15 & 21.33 \\
2- Fertilizer, superelfalah & 0.3 & 28.00 \\
(phosphate salt gm/kg) & 0.6 & 42.67 \\
& 0.9 & 72.00 \\
& 1.2 & 84.00 \\
\hline
\end{tabular}



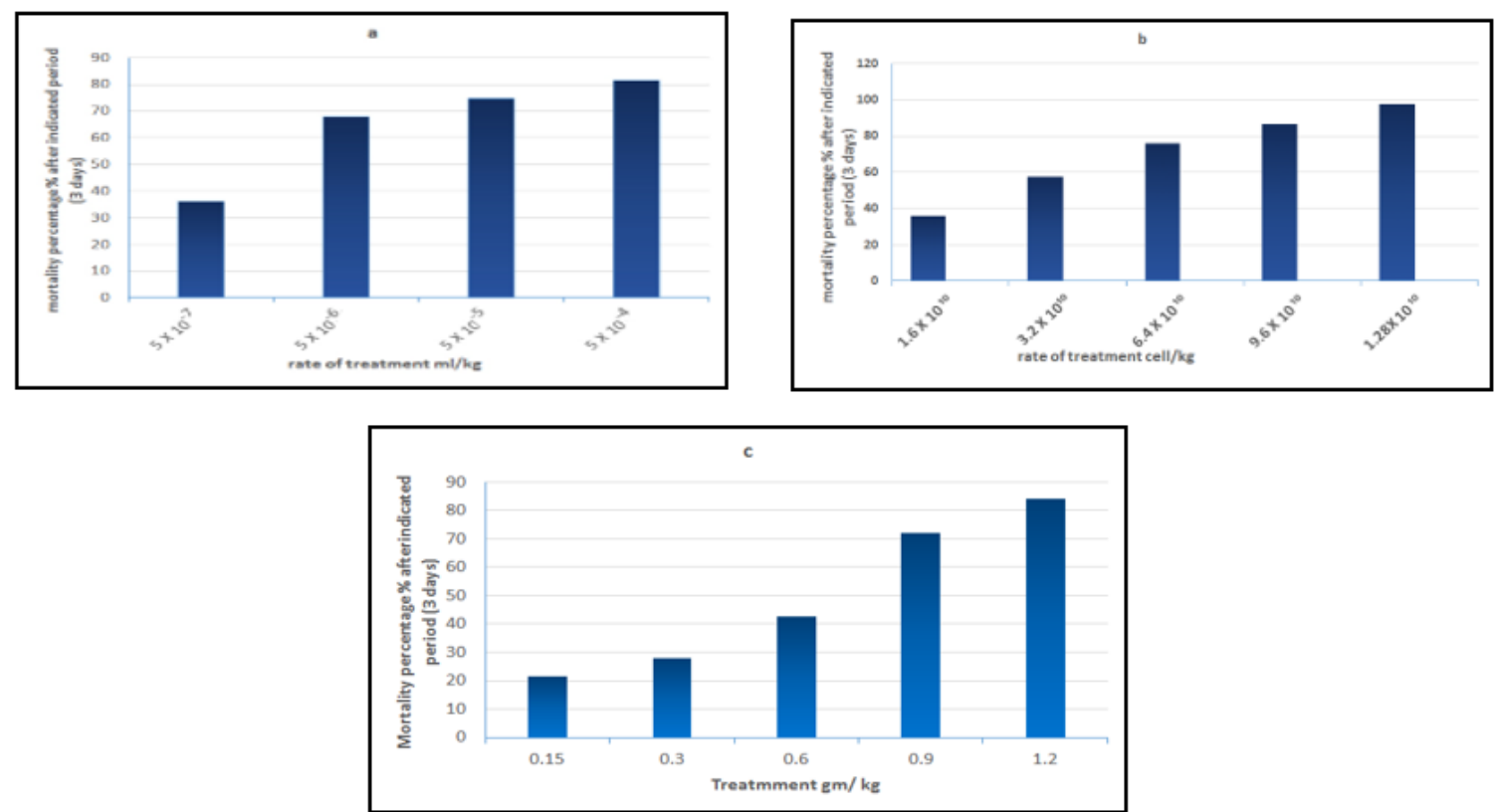

Fig. 2: Mortality percentage of $R$. dominica adult after different treatments with deltamethrin (a), Buvaria bassiana (b) and phosphate salt.

Data presented in (Table 4) demonstrated the $\mathrm{LC}_{25}, \mathrm{LC}_{50}, \mathrm{LC}_{75}, \mathrm{LC}_{90}, \mathrm{LC}_{95}$ and $\mathrm{LC}_{99}$ values after one day of exposure for $C$. maculatus and 3 days for $R$. dominica with the three test materials using Ldp line.

Table 4: Toxicological evaluation of deltamethrin, Buvaria bassiana, and phosphate salt (superelfalah) after one day of exposure against tested insect $C$. maculatus/ 3 days against $R$. dominica; (Concentrations = average of three replicate).

\begin{tabular}{|c|c|c|c|c|c|c|}
\hline \multirow{2}{*}{ Conc } & \multicolumn{2}{|c|}{$\begin{array}{c}\text { Deltamethrin } \\
(\mathbf{m l} / \mathbf{k g})\end{array}$} & \multicolumn{2}{c|}{$\begin{array}{c}\text { Buvaria bassiana } \\
\text { (cell/kg) }\end{array}$} & \multicolumn{2}{c|}{ Superelfalah (gm/kg) } \\
\cline { 2 - 7 } & C. maculatus & R.dominica. & C.maculatus & $\boldsymbol{R}$. dominica. & C. maculatus & R. dominica. \\
\hline LC25 & 0.0001 & - & 11.42 & 1.22 & 0.106 & 0.228 \\
\hline LC50 & 0.001 & 0.0000012 & 21.74 & 2.54 & 0.355 & 0.505 \\
\hline LC75 & 0.0114 & 0.000068 & 41.39 & 5.32 & 1.192 & 1.116 \\
\hline LC90 & 0.1034 & 0.002577 & 73.88 & 10.32 & 3.545 & 2.279 \\
\hline LC95 & 0.3878 & 0.02269 & 104.49 & 15.35 & 6.804 & 3.493 \\
\hline LC99 & 4.624 & 1.34198 & 200.23 & 32.32 & 23.111 & 7.778 \\
\hline
\end{tabular}

Results showed that there was a negative correlation between the mortality values and the time after application For C. maculatus the results showed $97.33 \%$ and $98.67 \%$ mortality at initial treatment then $100 \%$ up to three months treated with $\mathrm{LC}_{95}$ deltamethrin or LC ${ }_{95}$ Buvaria bassiana respectively. This agrees with (Ismail Oguz Ozdemir et al., 2020,) Data showed a sharp decline in the efficiency of the phosphate salt. It recorded $96 \%$ at initial treatment then, recorded $20 \%$ at the $4^{\text {th }}$ week and no effect was recorded on after $8^{\text {th }}$ week. This disagrees with (Antoin Sanon et al., 2010) who reported that deltamethrin failed to control C. maculatus after 3 months of storage (Table 5) and Figure (3) 
Table 5: Mortality percentage of $C$. maculatus adult exposed to $V$. faba seeds treated with $\mathrm{LC}_{95}$ of tested materials at storage periods

\begin{tabular}{|c|c|c|c|c|c|c|c|}
\hline \multirow{2}{*}{ Treatment } & \multicolumn{6}{|c|}{ Mortality \% at storage periods (weeks) } \\
\cline { 2 - 8 } & Initial & $\begin{array}{c}\mathbf{2}^{\text {nd }} \\
\text { week }\end{array}$ & $\begin{array}{c}\mathbf{4}^{\text {th }} \\
\text { week }\end{array}$ & $\begin{array}{c}\mathbf{6}^{\text {th }} \\
\text { week }\end{array}$ & $\begin{array}{c}\mathbf{8}^{\text {th }} \\
\text { week }\end{array}$ & $\begin{array}{r}\mathbf{1 0}^{\text {th }} \\
\text { week }\end{array}$ & $\begin{array}{r}\mathbf{1 2}^{\text {th }} \\
\text { week }\end{array}$ \\
\hline LC $_{95}$ Deltamethrin & 97.33 & 100 & 100 & 100 & 100 & 100 & 100 \\
\hline LC 95 Buvaria bassiana & 98.67 & 100 & 100 & 100 & 100 & 100 & 100 \\
\hline LC95 Superelfalah & 96 & 34.68 & 20 & 13.32 & --- & --- & --- \\
\hline
\end{tabular}
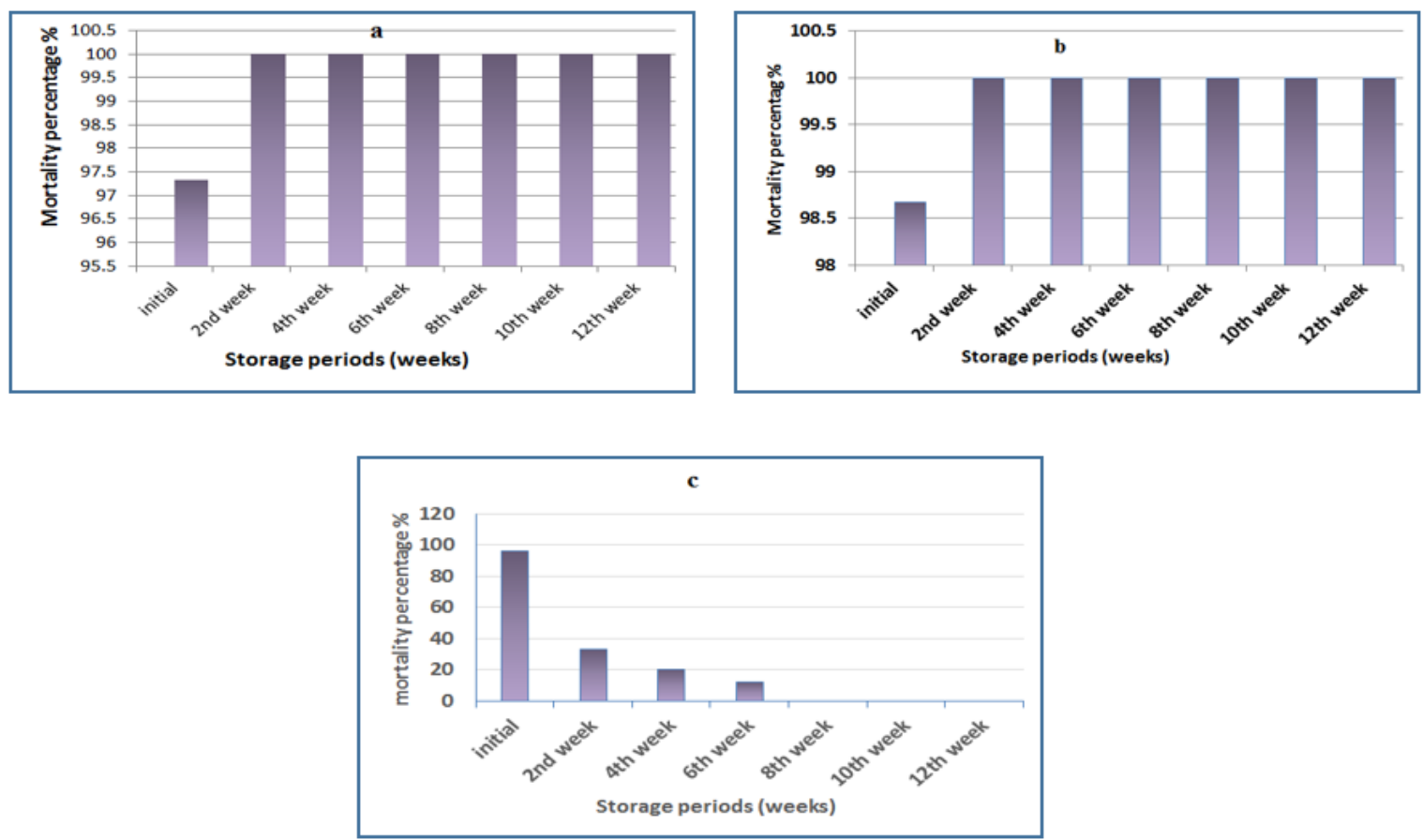

Fig.3: Mortality percentage of $C$. maculatus adult exposed to Vicia faba treated with $\mathrm{LC}_{95}$ of deltamethrin (a), Buvaria bassiana (b) and Superelfalah (c) at storage periods

For $R$. dominica at initial treatment $98.67 \%$ mortality were recorded with adults affected by $\mathrm{LC}_{95}$ of Buvaria bassiana, then $100 \%$ at the second week up to the end of the storage period (3 months) indicating the high residual effect of this bio-insecticide. Mortality percentage recorded $89 \%$ by the end of the storage period when $R$. dominica was exposed to T. durum treated with $\mathrm{LC}_{95}$ deltamethrin which agrees with (Nasr, M. E. H. and S.M. Mahgoub., 2017). A sharp decline in the efficiency of phosphate salt occurred after six weeks which recorded $46.67 \%$ at the $6^{\text {th }}$ week (Table 6 and Fig.4).

Table 6: Mortality percentage of $R$. dominica adult exposed to $T$. durum grains treated with $\mathrm{LC}_{95}$ of tested materials at storage periods.

\begin{tabular}{|c|c|c|c|c|c|c|c|}
\hline \multirow[b]{2}{*}{ Treatment } & \multicolumn{7}{|c|}{ Mortality \% storage periods (weeks) } \\
\hline & Initial & $\begin{array}{c}2^{\text {nd }} \\
\text { week }\end{array}$ & $\begin{array}{c}4^{\text {th }} \\
\text { week } \\
\end{array}$ & $\begin{array}{c}6^{\text {th }} \\
\text { week }\end{array}$ & $\begin{array}{c}8^{\text {th }} \\
\text { week }\end{array}$ & $\begin{array}{r}10^{\text {th }} \\
\text { week }\end{array}$ & $\begin{array}{r}12^{\text {th }} \\
\text { week }\end{array}$ \\
\hline LC $_{95}$ Deltamethrin & 97.33 & 90.86 & 90 & 90 & 90 & 90 & 89.33 \\
\hline $\mathrm{LC}_{95}$ Buvaria bassiana & 98.67 & 100 & 100 & 100 & 100 & 100 & 100 \\
\hline LC95 Superelfalah & 98.67 & 84 & 54.76 & 46.67 & - & - & - \\
\hline
\end{tabular}



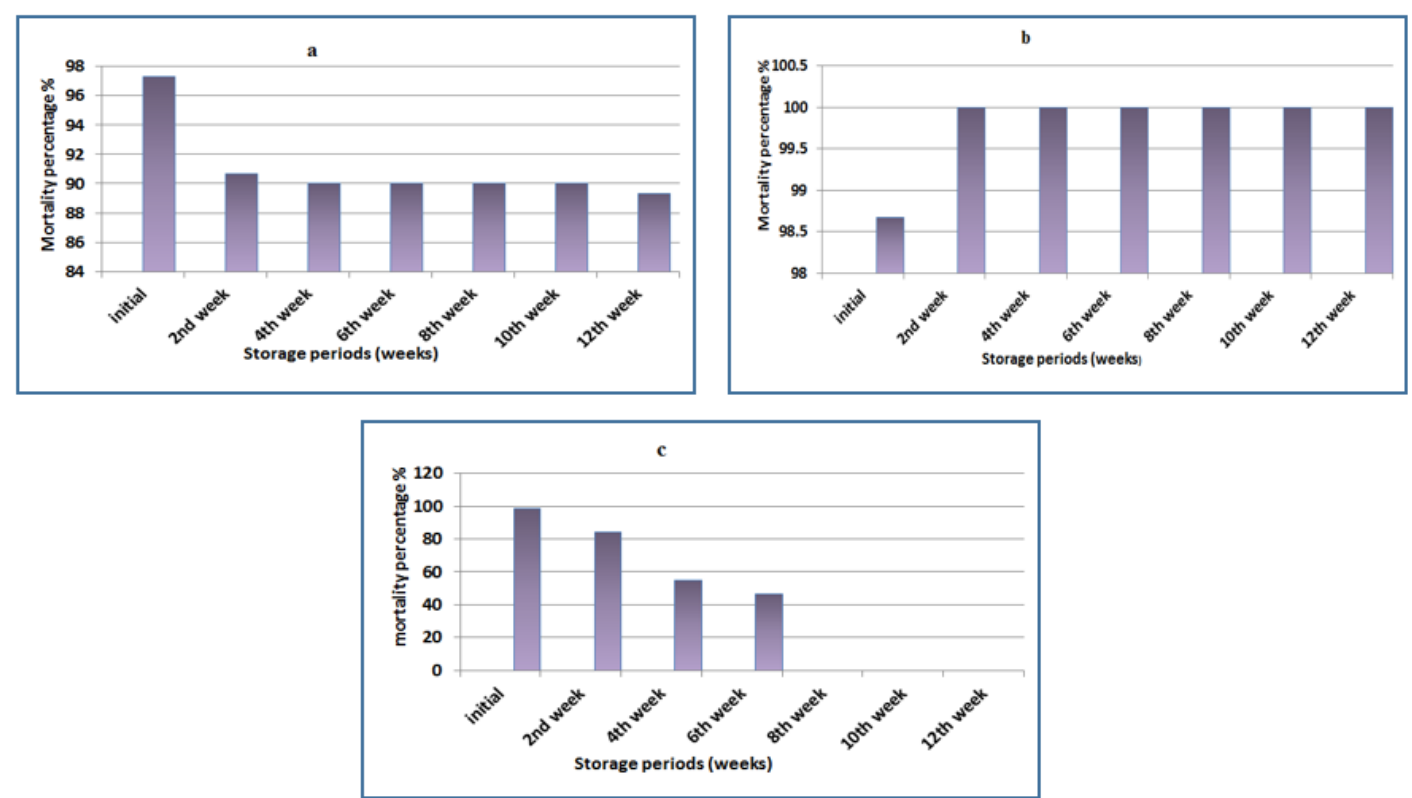

Fig.4: Mortality percentage of $R$. dominica adult exposed to $T$. durum grains treated with LC 95 of deltamethrin (a), Buvaria bassiana (b), and superelfalah (C) storage periods.

\section{Germination Test:}

Data showed that germination of $V$. faba seeds treated with deltamethrin at the $\mathrm{LC}_{95}$ concentration remained almost equal to the control (100\%) at the initial and after storage period ( 3 months) while Buvaria bassiana and phosphate salt indicated a $1.33 \%$ reduction in germination at the initial time only (Table 7 and Fig. 5). This agrees with (Nasr, M. E. H. and S.M. Mahgoub., 2017 El-Khayat., 2000) disagree with (Yacoub Ahmad Batta., 2008, J. M. Adesina et al., 2012).

Table 7: Germination percentage of $V$. faba seeds treated with deltamethrin, Buvaria bassiana and superelfalh at initial and after storage periods.

\begin{tabular}{|c|c|c|c|c|c|}
\hline \multicolumn{2}{|c|}{$\begin{array}{l}\text { Treatment } \\
\mathrm{ml} / \mathrm{Kg}\end{array}$} & Control & $\begin{array}{c}\mathrm{LC}_{95} \\
\text { deltamethrin }\end{array}$ & $\begin{array}{c}\mathrm{LC}_{95} \\
\text { Buvaria bassiana }\end{array}$ & $\begin{array}{c}\mathbf{L C} \mathbf{C}_{95} \\
\text { superelfalah }\end{array}$ \\
\hline \multirow{2}{*}{ 。 } & Initial & 100 & 100 & 98.67 & 98.67 \\
\hline & $\begin{array}{l}\text { After } \\
\text { storage }\end{array}$ & 100 & 100 & 100 & 100 \\
\hline
\end{tabular}
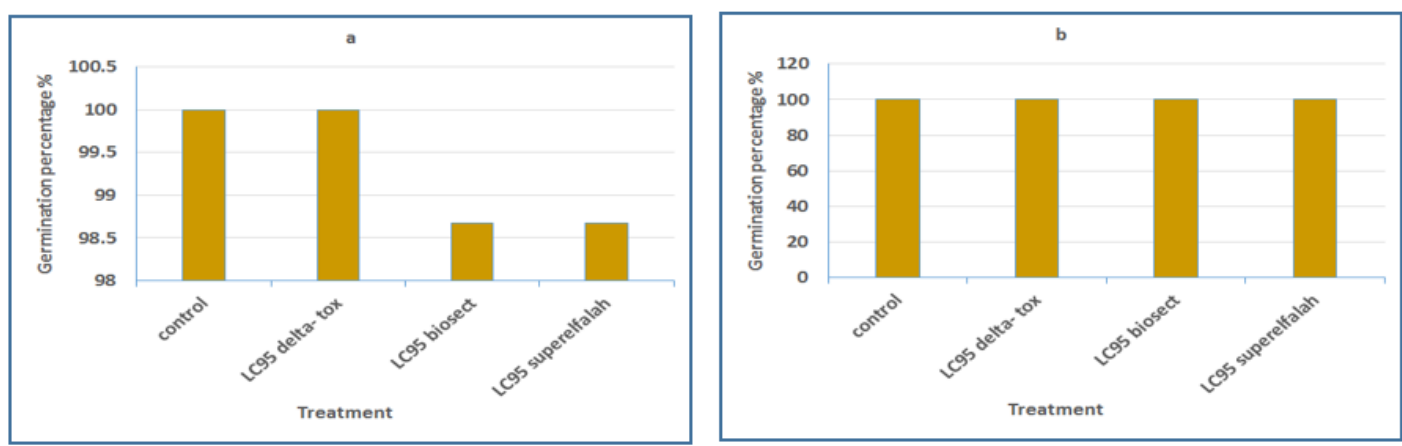

Fig.5: Germination percentage of $V$. faba seeds treated with deltamethrin, Buvaria bassiana and superelfalah at initial (a) treatment and after storage periods (b). 
Data in Table (8) showed that germination of wheat grain treated with $\mathrm{LC}_{95}$ of deltamethrin remained almost equal to the control (100\%) at the initial and after the storage period. Buvaria bassiana and phosphate salt indicated a reduction in germination at the initial time only (Fig. 6).

Table (8): Germination percentage of T. durum grains treated deltamethrin, Buvaria bassiana and superelfalah at initial treatment and after storage periods.

\begin{tabular}{|c|c|c|c|c|c|}
\hline \multicolumn{2}{|c|}{$\begin{array}{l}\text { Treatment } \\
\mathrm{ml} / \mathrm{Kg}\end{array}$} & Control & $\begin{array}{c}\mathrm{LC}_{95} \\
\text { Deltamethrin }\end{array}$ & $\begin{array}{c}\mathrm{LC}_{95} \\
\text { Buvaria bassiana }\end{array}$ & $\begin{array}{c}\mathrm{LC}_{95} \\
\text { superelfalah }\end{array}$ \\
\hline \multirow{2}{*}{ 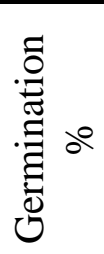 } & Initial & 100 & 100 & 98.67 & 97.33 \\
\hline & $\begin{array}{l}\text { After } \\
\text { storage }\end{array}$ & 100 & 100 & 100 & 100 \\
\hline
\end{tabular}
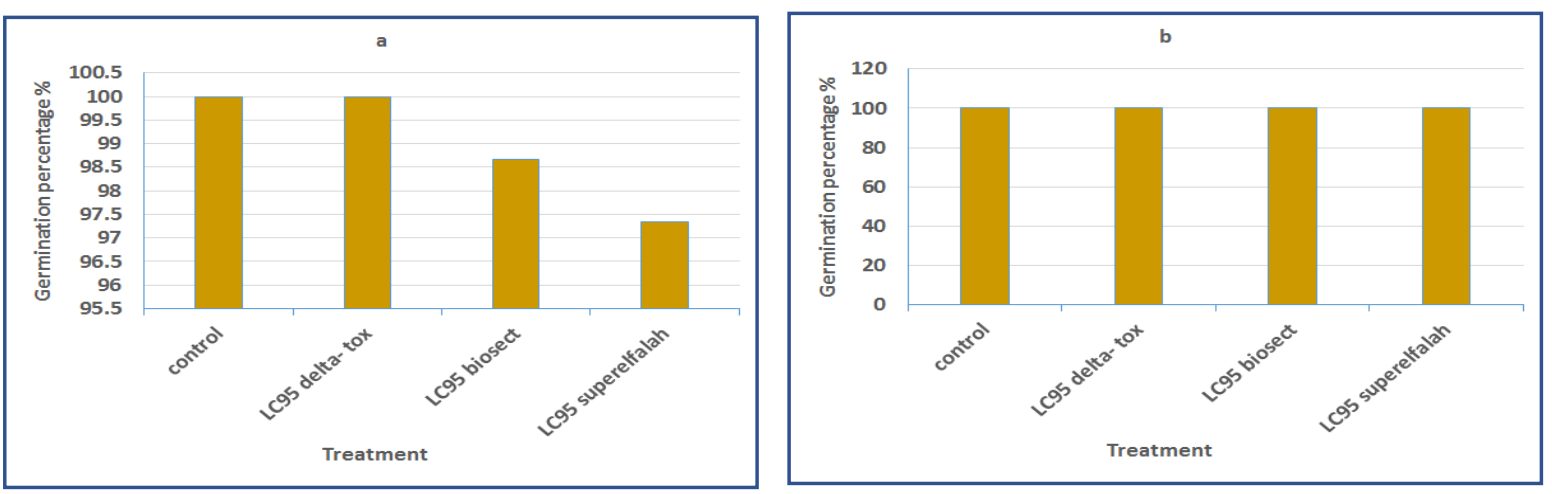

Fig.6: Germination percentage of T. durum seeds treated with deltamethrin, Buvaria bassiana and superelfalah at initial (a) treatment and after storage periods (b).

\section{Water Absorption:}

Water absorption of $V$. faba seeds and T. durum grains after the indicated times of dipping $(1,4,24$ hours). water absorption increased with the extension of the submerging period (Tables $9 \& 10)$ and Figures $(7 \& 8)$. There is no significant difference in the percentage of water absorption was recorded between the treated and untreated $V$. faba seeds/ T. durum grains.

Table 9: Water absorption percentage of $V$. faba treated with deltamethrin, Buvaria bassiana and phosphate salt at initial and after storage periods.

\begin{tabular}{|c|c|c|c|c|}
\hline \multirow{2}{*}{\multicolumn{2}{|c|}{ Tested material }} & \multicolumn{3}{|c|}{ Water absorption \% for $V \cdot f a b a$} \\
\hline & & \multirow{2}{*}{$\begin{array}{c}\text { 1 hour } \\
13.55\end{array}$} & \multirow{2}{*}{$\frac{4 \text { hour }}{37.50}$} & \multirow{2}{*}{$\begin{array}{l}24 \text { hour } \\
107.17\end{array}$} \\
\hline \multirow{4}{*}{ 祃 } & Control & & & \\
\hline & Deltamethrin & 22.23 & 45.70 & 104.80 \\
\hline & Buvaria bassiana & 18.30 & 44.08 & 115.04 \\
\hline & Superelfalah & 22.00 & 33.07 & 102.79 \\
\hline \multirow{4}{*}{ 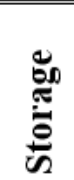 } & Control & 1.38 & 29.30 & 105.01 \\
\hline & Deltamethrin & 7.39 & 46.85 & 106.89 \\
\hline & Buvaria bassiana & 13.78 & 43.06 & 111.79 \\
\hline & Superelflah & 4.59 & 32.90 & 102.80 \\
\hline
\end{tabular}




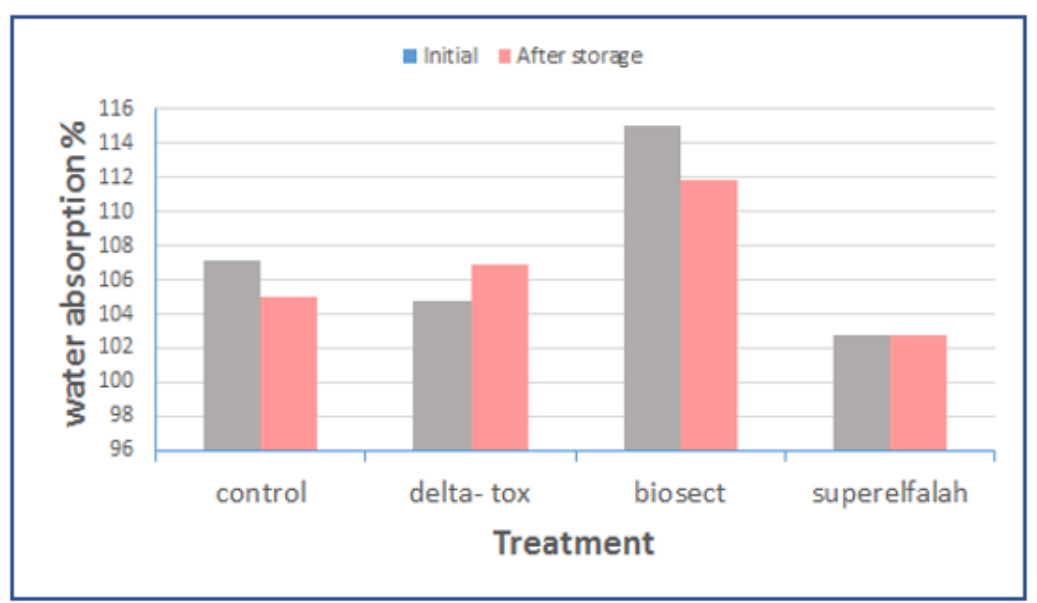

Fig.7. Water absorption percentage after 24 hours of $V$. faba seeds treated with deltamethrin, Buvaria bassiana and phosphate salt at initial and after storage periods.

Table 10: Water absorption percentage of $T$. durum treated with deltamethrin, Buvaria bassiana and superelflah at initial and after storage periods.

\begin{tabular}{|c|l|c|c|c|}
\hline \multirow{2}{*}{ Tested material } & \multicolumn{3}{|c|}{$\begin{array}{c}\text { Water absorption \%for } \\
\text { T. durum }\end{array}$} \\
\cline { 3 - 5 } & Control & 13.96 & 23.21 & 47.02 \\
\hline \multirow{4}{*}{ Initial } & hour & 4 hour & $\mathbf{2 4}$ hour \\
\cline { 2 - 5 } & Deltamethrin & 13.20 & 24.74 & 47.35 \\
\cline { 2 - 5 } & Buvaria bassiana & 14.10 & 24.13 & 49.33 \\
\cline { 2 - 5 } & Phosphate salt & 13.05 & 24.35 & 46.15 \\
\hline \hline \multirow{5}{*}{ Storage } & Control & 11.29 & 21.97 & 43.36 \\
\cline { 2 - 5 } & Deltamethrin & 9.99 & 18.26 & 43.81 \\
\cline { 2 - 5 } & Buvaria bassiana & 14.39 & 18.28 & 43.96 \\
\cline { 2 - 5 } & Superelfalah & 10.09 & 21.48 & 40.36 \\
\hline
\end{tabular}

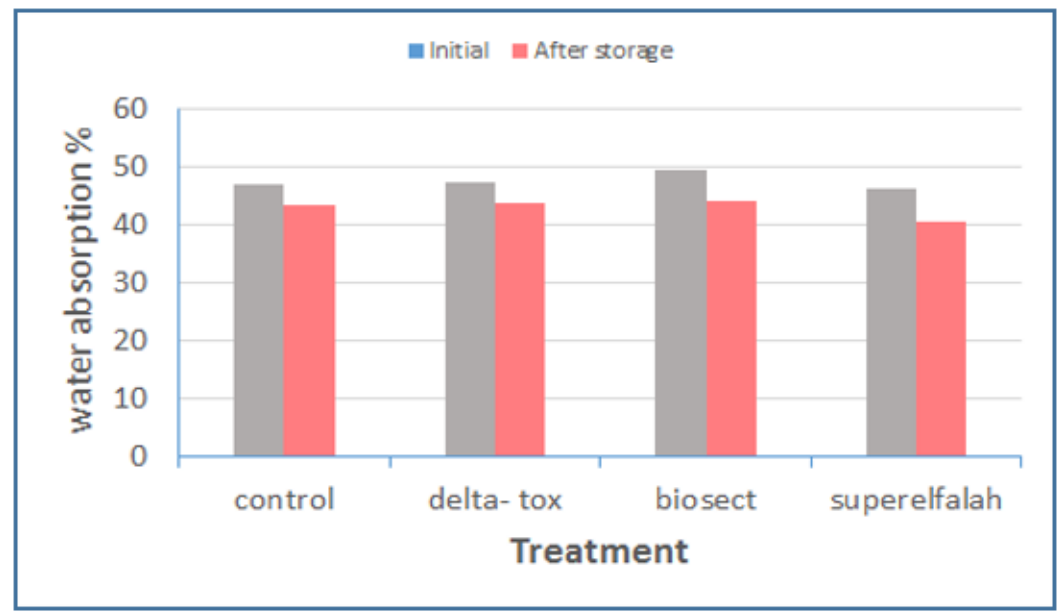

Fig.8. Water absorption percentage after 24 hours of $T$. durum grains treated with deltamethrin, Buvaria bassiana and phosphate salt at initial and after storage periods. 


\section{REFERENCES}

Abbot, W.S. (1925): A method of computing the effectiveness of an insecticide. Journal of Economic Entomology, 18 (2): 265-267

Abelfatth S. A. Saad, E. H. M. Tayeb, M. M. El-Shazli and S. A. Baheeg. (2018): Susceptibility of certain Egyptian and imported wheat cultivars to infestation by Sitophilus oryzae and Rhyzopertha dominica. Archives of Phytopathology and Plant Protection,51 (1- 2): 14- 29.

Adesina, J.M.; Afolabi, L.A. and Ofuya, T.I. (2012): Evaluation of insecticidal properties of Momordica charantia in reducing oviposition and seed damaged by Callosobruchus maculatus (Fab.) Walp Journal of Agricultural Technology, 8(2): 493-499

Anestis Karkanis. ; Georgia Ntatsi.; Liga Lepse.; Juan A. Fernández.; Ingunn M. Vågen.; Boris Rewald.; Ina Alsin.; Arta Kronberga.; Astrit Balliu.; Margit Olle.; Gernot Bodner.; Laila Dubova.; Eduardo Rosa and Dimitrios Savvas. (2018). Faba Bean Cultivation - Revealing Novel Managing Practices for More Sustainable and Competitive European Cropping Systems. Frontiers in plant science.9: 1115.

Anonymus (1966): International Rules for Seed Testing. Procedure International Seed testing, XXXI, 49-9.

Beres, B.L.; Rahmani, E.; Clarke, J.M.; Grassini, P.; Pozniak, C.J.; Geddes, C.M.; Porker, K.D.; May, W.E.; Ransom, J.K. A systematic review of durum wheat. (2020): Enhancing production systems by exploring genotype, environment, and management $(\mathrm{G} \times \mathrm{E} \times \mathrm{M})$ synergies. Front. Plant Sci.11: 568657 .

Bliss, C. J. (1935): The calculation of dosage mortality curve. Annals of Applied Biology, 22 (1): 134-167.

Edde, P.A. A. (2012): review of the biology and control of Rhyzopertha dominica (F.) the lesser grain borer. Journal of Stored Products Research, 48, 1-18.

El-Khayat, E. F. (2000): Laboratory studies on the effectiveness of certain biocontrol agents against some stored grain insects. Annals of Agricultural Science, 38:2, 1235-1245.

Kogan M. (1994): Plant resistance in pest management. In: Metcalf, R and Luckmann (eds.), Introduction to pest management, John Wiley and Sons, Inc. New York, pp. 73128.

Lale N. E. S. (1991). The biological effects of three essential oils on Callosobruchus maculatus (F.) (Coleoptera: Bruchidae). Revue de Zoologie Africaine, 105: 357362.

Lale N. E. S. and Ofuya T. T. (2001). Pest of stored cereals and pulses in Nigeria; Biology, Economy and Control. Dave Collins Publications, Akure, Nigeria. pp. 2-57.

Marijana Pražić Golić.; Petar Kljajić.; Goran Andrić.; Nenad Tamaš.; and Stefan Pražić. (2018): Pesticidi i fitomedicina, 33(2): 127: 135.

Nasr, M.E.H. and S.M. Mahgoub (2017). Residual activity and persistence of deltamethrin insecticide on different surfaces against Sitophilus oryzae (L.) and Rhyzopertha dominica (F.). Egyptian Journal of Agriculture Research, 95(4), 2017

Ozdemir, I.O., Tuncer, C., Erper, I., Kushiyev, R. (2020): Efficacy of the entomopathogenic fungi; Beauveria bassiana and Metarhizium anisopliae against the cowpea weevil, Callosobruchus maculatus F. (Coleoptera: Chrysomelidae: Bruchinae), Egyptian Journal of Biological Pest Control, 30(24). https://doi.org/10.1186/s41938-02000219-y

Potter C. (1935): The biology and distribution of Rhyzopertha dominica (Fab.). Transactions of the Royal Entomological Society of London, 83, 449-482. 
Rasha E. Saber.; Mawaheb M. Zewar and Hala M. Mahfouz. (2017): Efficacy and Residual Activity of Some Plant Oils, Abamectin bio-insecticide and Their Mixtures Against Cowpea Seed Beetle, Callosobruchus maculatus (F.). (Coleoptera: Bruchidae). Egyptian Academic Journal of Biological Science A.Entomology, Vol.10(1): 1-8.

Sall A.T.1., T. Chiari., W. Legesse., S. Ahmed., R. Orti., M. van Ginkel and F.M. Bassi. (2019): Durum Wheat (Triticum durum Desf.) Origin, Cultivation, and Potential Expansion in Sub-Saharan Africa. Agronomy. 9: 263.

Van Emden, HF (1966). Plant insect relationships and pest control. World Rev. Pest Control, 5: $115-123$.

Wooldbridge AW, Harrison FP. (1968): Effect of soil fertility on abundance of green peach aphid on Maryland tobacco. Journal of Economic Entomology, 61: 387-391.

Yacoub Ahmad Batta. (2008): Control of Main Stored-Grain Insects with New Formulations of Entomopathogenic Fungi in Diatomaceous Earth Dusts. International Journal of Food Engineering, 10(1): 9.

Z. Mahdneshin.; M. Hassan Safaralizadah and Y. Ghosta. (2019): Study on the Efficacy of Iranian Isolates of Beauveria bassiana (Balsamo) Vuillemin and Metarhizium anisopliae (Metsch.) Sorokin Against Rhyzopertha dominica F. (Coleoptera: Bostrichidae). Journal of Biological Science, 9 (2): 170- 174.

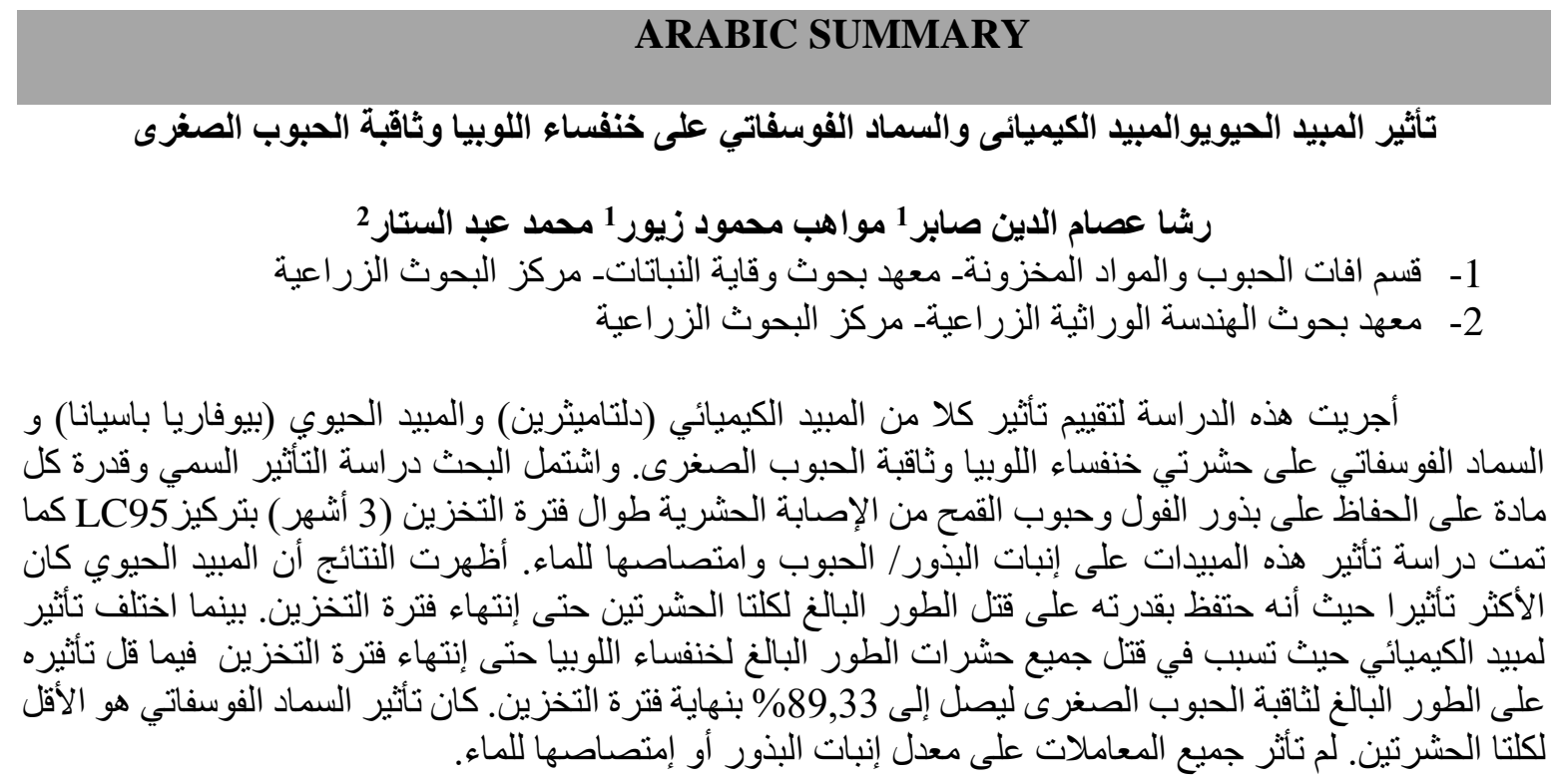

